\title{
An Ergonomic Forklift Training Program
}

\section{Daniel C1, Priyadarshini DG ${ }^{2 *}$, William $\mathrm{CC}^{3}$ and Lawrence $\mathbf{M}^{2}$}

${ }^{1}$ College of Business, Southeastern Louisiana University, USA

${ }^{2}$ Department of Industrial and Engineering Technology, Occupational Health and Safety

Concentration, Southeastern Louisiana University, USA

${ }^{3}$ Riverland Industries as Safety Coordinator, Baton Rouge, Louisiana, USA

\section{Research Article}

Volume 3 Issue 4

Received Date: June 10, 2019

Published Date: July 29, 2019

DOI: $10.23880 /$ eoij-16000212

*Corresponding author: Priyadarshini Dasgupta, Department of Industrial and Engineering Technology, Occupational Health and Safety Concentration, Southeastern Louisiana University, USA, Tel: 985549 3355; Email: priyadarshini.dasgupta@selu.edu

\section{Abstract}

Training programs rarely focus on projecting skills as part of activities to finish a task. We have used a sample forklift training program as a model training program. The uniqueness of this is that it includes instructional objectives and describes an intended outcome (as a skill) of instruction. We have divided the forklift operation into several tasks, stratified each task into different steps and each steps into different activities. The activities are the main performance which are expected from the operators. If the performance is a covert one, an indicator behavior was also attached. Each activity was focused as an imperative skill without which the performance of the trainees were deemed incomplete. We compared our developed training program with other existing programs in order to find its efficacy in retaining the training material. To attain a maximum training effectiveness we strongly recommended a criterion testing to evaluate the skills following our training program.

Keywords: Training Program; Forklifts; Policy

\section{Introduction}

Most companies in many industries have the need for forklifts. Whether it is for stocking, transporting, or other, forklifts serve as an essential tool for many businesses around the world. As common as forklifts are found in workplaces everywhere, one would think that it is a very safe task to drive and operate this machinery. However, this is not the case at all. In fact, forklift accidents result in nearly $10 \%$ of all physical injuries in the workplace. This should not be this high because, according to OSHA, 70\% of all forklift related injuries could be avoided with proper training and policy. Existing forklift training programs are poor in delivering the needed skills to the trainees and thus they get a partial knowledge about how to safely maneuver forklifts.

These statistics make one wonder as to why current forklift training programs aren't doing their job to protect workers from injuries. To answer this question, several forklift training manuals were researched, as well as several articles having to do with skill-based training. The objective of this paper is to prepare a skill-based training program beneficial to industries that rely on forklifts or other powered industrial trucks. 


\section{Ergonomics International Journal}

\section{Background}

We began to research different training programs, several were found that provided less understanding of the tasks, steps and skills and contained a lot less importance on acquiring necessary skills. This does not mean that it is lacking information, but that other training programs were also excessive and repetitive. We were able to find six additional outside forklift training programs to compare to the one that we developed. Different training programs have been summarized under (Table 1).

\begin{tabular}{|c|c|c|c|}
\hline Training Program & Content of Training Program & Disadvantages & Advantages \\
\hline \multirow{3}{*}{$\begin{array}{c}\text { “Forklift Safety Guide: State } \\
\text { of Washington” }\end{array}$} & -Essay-style format & -Lengthy & -Very thorough overall \\
\hline & $\begin{array}{l}\text {-Included information about the } \\
\text { different types of forklifts, training, } \\
\text { how forklifts work, how to use a } \\
\text { forklift, hazards, and maintenance }\end{array}$ & $\begin{array}{l}\text {-Did not go as much into } \\
\text { detail about skills as the } \\
\text { formulated forklift } \\
\text { training program }\end{array}$ & \multirow[t]{2}{*}{$\begin{array}{l}\text {-Touched on very } \\
\text { important subjects }\end{array}$} \\
\hline & -Occasional charts and diagrams & $\begin{array}{l}\text {-Too many pictures that } \\
\text { distracted from the point }\end{array}$ & \\
\hline \multirow{3}{*}{$\begin{array}{l}\text { "San Jose State University: } \\
\text { Forklift Training Manual" }\end{array}$} & -Paragraph format & -Lengthy & $\begin{array}{l}\text {-Covered on several } \\
\text { notable subjects }\end{array}$ \\
\hline & \multirow{2}{*}{$\begin{array}{l}\text {-Touched on visibility factors, } \\
\text { capacity of the vehicle, vehicle } \\
\text { stability, controls, and proper } \\
\text { inspections }\end{array}$} & $\begin{array}{l}\text {-Covered less tasks than } \\
\text { the given program }\end{array}$ & \multirow{2}{*}{$\begin{array}{l}\text {-Not very difficult to } \\
\text { follow }\end{array}$} \\
\hline & & -Minimal graphics & \\
\hline \multirow{3}{*}{$\begin{array}{l}\text { "Forklift Training for } \\
\text { Trainers" }\end{array}$} & -Very thorough essay-type format & $\begin{array}{l}\text {-Did not go as much into } \\
\text { detail as the given } \\
\text { program }\end{array}$ & $\begin{array}{l}\text {-Lightly hit on all the } \\
\text { tasks covered in the } \\
\text { given forklift training } \\
\text { program } \\
\end{array}$ \\
\hline & \multirow{2}{*}{$\begin{array}{c}\text {-A large number of images and } \\
\text { pictures }\end{array}$} & \multirow{2}{*}{$\begin{array}{l}\text {-The pictures and } \\
\text { graphics drew away the } \\
\text { attention from the } \\
\text { subject matter }\end{array}$} & $\begin{array}{l}\text {-Some graphics were } \\
\text { helpful }\end{array}$ \\
\hline & & & $\begin{array}{c}\text {-Covered a large scope } \\
\text { of information }\end{array}$ \\
\hline \multirow{3}{*}{$\begin{array}{c}\text { "Sample Forklift Safety and } \\
\text { Powered Industrial Trucks } \\
\text { Written Program" }\end{array}$} & -Paragraph form & $\begin{array}{c}\text {-No charts, images, or } \\
\text { visuals }\end{array}$ & $\begin{array}{l}\text {-Contained some good } \\
\text { information on forklifts }\end{array}$ \\
\hline & \multirow[b]{2}{*}{-Very lengthy } & -Difficult to follow & \multirow[b]{2}{*}{$\begin{array}{c}\text {-Contained a small quiz } \\
\text { at the end }\end{array}$} \\
\hline & & $\begin{array}{l}\text {-Lacked organization as } \\
\text { well as some key details }\end{array}$ & \\
\hline \multirow{3}{*}{$\begin{array}{l}\text { "Craven Community College } \\
\text { Forklift Safety Program" }\end{array}$} & $\begin{array}{l}\text {-Much longer than the given } \\
\text { program }\end{array}$ & $\begin{array}{c}\text {-Heavily consisted on } \\
\text { recording and evaluation } \\
\text { forms }\end{array}$ & \multirow{3}{*}{$\begin{array}{l}\text {-Touched on all of the } \\
\text { tasks included in the } \\
\text { given program }\end{array}$} \\
\hline & -Paragraph format & $\begin{array}{l}\text {-Went less into detail } \\
\text { pertaining to certain } \\
\text { skills }\end{array}$ & \\
\hline & & -difficult to follow & \\
\hline \multirow{2}{*}{$\begin{array}{l}\text { "University of Pittsburgh: } \\
\text { Safety Requirements- } \\
\text { Powered Industrial Truck } \\
\text { Program" }\end{array}$} & -Essay-type format & $\begin{array}{l}\text {-Did not include some } \\
\text { graphics that may have } \\
\text { been helpful }\end{array}$ & $\begin{array}{l}\text {-Included all of the } \\
\text { tasks that the given } \\
\text { program contained }\end{array}$ \\
\hline & $\begin{array}{l}\text {-Touched on many important } \\
\text { factors of forklift training }\end{array}$ & $\begin{array}{l}\text {-Did not include the } \\
\text { steps or skills required } \\
\text { for those steps }\end{array}$ & $\begin{array}{l}\text {-Not the hardest to } \\
\text { follow }\end{array}$ \\
\hline
\end{tabular}

Table 1: Disadvantages of existing training programs. 


\section{Ergonomics International Journal}

\section{Methods}

A job is usually made up of series of tasks. Task is a series of actions or steps leading to a meaningful outcome or result. A task analysis of the entire training subject (forklift training) was carried out as the first step. Task analysis allows us to know what people do when they perform a job. Thus, task analysis has two elements which are task listing and task detailing. Task listing identifies each of the tasks someone performs when doing a job. Task detailing are the steps and decisions required in a specific task. For each of the tasks identified within the job of forklift training, a terminal objective was written.

The terminal objective was the ultimate goal of preparing these tasks. This was the second step for developing the training program. An objective is a description of a performance that the trainer wants the learners to be able to exhibit before they consider it competent. The training program was designed to teach those objectives to assure that the learner's needs were met. An objective was described as the intended result of the instruction, rather than the process of the instruction itself.

The third step was to identify the skills associated with the correct performance of the task that need to be completed. Each of the activity to perform a task requires various skills. Often, each of the tasks requires skills unlike those required for the other tasks. a) It was used in our study to develop the list of skills that would be necessary for anyone to perform the task. b) By task analysis we were able to single out each of the skills required to perform the terminal objective and how the skills were related to each other, i.e., which ones must be learned before others can be attempted. This skill hierarchy was the primary source of information for developing the training map. c) The useful skills to learn in developing skill objectives were singled out and shorthand was written for them. For example, suppose we are dealing with a course in auto repair and one of the subordinate objectives read "given access to all tools, materials and standard equipment of a service station, and a flat tire having a single puncture, repair the tire; time limit is twenty minutes. Useful shorthand names for that objective would be repair flat tire and fix flat tire. We always tested to make it sure we have described an action rather than knowledge. d) Skill hierarchies looked like organization charts. The hierarchies were wider than they were long. We selected each task as we knew how to perform it. We began by drafting a terminal objective that is the expected final performance.

The fourth step was to write clear and properly stated objectives for each of the skills identified. Each objective (of the skills) was written using the format a) action, b) behavior and c) conditions and d) degree. Where the action/behavior was cognitive, it was written in such a manner that used an observable behavior, or indicator behavior, to demonstrate what was expected. Special focus was given that the verb that was used to describe a desirable behavior was observable. The fifth step was to write criterion item(s) for each of the skills/objectives and to write a skill check (test question, observation, etc.). This was necessary to demonstrate that the trainee has learned the skill [1-4].

We reviewed the terminal objective and answered this question: what are the skills that made up this performance. We then located the major sub-skills and placed them in a row under the terminal objectives. e) We tested if the terminal objective and the sub-skill were independent to each other. We did this by asking, is it true that either of these two skills can be learned without knowing how to do the other one? f) In a similar fashion, we added the remaining skills to the hierarchy, placing them under the skill(s) they are subordinate to. We drew lines in pencil to show the relationships between the skills.

\section{Results}

Table 2 shows the developed training program. Column 1 shows the tasks, column 2 shows the terminal objectives of each task and column 3 shows the skills associated with each terminal objective.

\begin{tabular}{|c|l|l|l|}
\hline Task \# & \multicolumn{1}{|c|}{ Task } & Terminal Objectives/Understanding & \multicolumn{1}{c|}{ Skill } \\
\hline 1. & $\begin{array}{c}\text { Operating instructions, } \\
\text { warnings, and precautions }\end{array}$ & 1.1 Instructions for safe operation & $\begin{array}{l}\mathbf{1 . 1 . 1} \text { Ability to identify all the } \\
\text { instructions that are needed to be } \\
\text { abided } \\
\mathbf{1 . 2 . 1} \text { Ability to abide by all warnings } \\
\text { and precautions provided by OSHA }\end{array}$ \\
\hline 2. & Differences between the lift & $\mathbf{2 . 1}$ Steering differences & $\mathbf{2 . 1 . 1}$ Ability to differentiate the \\
\hline
\end{tabular}

Priyadarshini DG, et al. An Ergonomic Forklift Training

Program. Ergonomics Int J 2019, 3(4): 000212. 


\section{Ergonomics International Journal}

\begin{tabular}{|c|c|c|c|}
\hline & truck and an automobile & 2.2 Load position & $\begin{array}{l}\text { backwards steering in a lift truck to } \\
\text { forward steering in an Automobile } \\
\text { 2.2.1 Knowledge that a lift trucks } \\
\text { load is in front and automobile's load } \\
\text { is kept in back }\end{array}$ \\
\hline 3. & Controls \& instrumentations & $\begin{array}{l}\text { 3.1 Control functions } \\
\text { 3.2 Instrumentations }\end{array}$ & $\begin{array}{l}\text { 3.1.1 Knowledge of forklift controls } \\
\text { pertaining to location, function and } \\
\text { how to use } \\
\text { 3.2.1 Knowledge of forklift } \\
\text { Instrumentations pertaining to } \\
\text { location, function and how to use }\end{array}$ \\
\hline 4. & Engine or motor operations & 4.1 Engine controls & $\begin{array}{l}\text { 4.1.1 Knowledge of the basic } \\
\text { Engine/motor functions of your lift } \\
\text { truck }\end{array}$ \\
\hline 5. & Steering and maneuvering & $\begin{array}{l}\text { 5.1 Apply a safety practice for } \\
\text { climbing onto the forklift } \\
\text { 5.2 Identify the proper sound that } \\
\text { the forklift should be making } \\
\text { 5.3 Demonstrate an ability to drive } \\
\text { the forklift in the shipping area } \\
\text { 5.4 Recognize possible problems } \\
\text { with the while operating the forklift } \\
\text { 5.5 Demonstrate the ability to drive } \\
\text { the forklift in reverse }\end{array}$ & $\begin{array}{l}\text { 5.1.1 The user should be able to } \\
\text { climb onto the forklift using three } \\
\text { points of contact } \\
\text { 5.2.1 The user should be aware of } \\
\text { possible unusual noises } \\
\text { 5.3.1 The user should be able to } \\
\text { have the ability to maneuver } \\
\text { 5.4.1 The user should be able to } \\
\text { show ability to be aware of possible } \\
\text { malfunctions in the forklift. } \\
\text { 5.5.1 The user should be able to } \\
\text { drive in reverse }\end{array}$ \\
\hline 6. & Visibility & $\begin{array}{l}\text { 6.1 Visibility with load } \\
\begin{array}{l}6.2 \text { Visibility for looking for } \\
\text { pedestrians }\end{array} \\
\begin{array}{l}6.3 \text { Visibility for other forklifts or } \\
\text { people to see you }\end{array}\end{array}$ & $\begin{array}{l}\text { 6.1.1 Ability to maintain visibility } \\
\text { when traveling with a load } \\
\text { 6.1.2 Knowledge of when a spotter is } \\
\text { needed or when to travel in reverse } \\
\text { 6.2.1 Ability to stay aware and look } \\
\text { for pedestrians } \\
\text { 6.3.1 Ability to make yourself known } \\
\text { by sounding horn and ensure backup } \\
\text { lights work so that bystanders and } \\
\text { other lifts are aware of your location }\end{array}$ \\
\hline 7. & $\begin{array}{c}\text { Fork and attachment } \\
\text { daptation, operation, and us } \\
\text { limitations }\end{array}$ & $\begin{array}{l}\text { 7.2 Forklift attachment operation } \\
\begin{array}{l}7.3 \quad \text { Forklift attachment use } \\
\text { limitations }\end{array}\end{array}$ & $\begin{array}{l}\text { 7.1.1 Knowledge of forklift } \\
\text { manufacturer attachment approvals } \\
\text { 7.1.2 Ability to properly add an } \\
\text { attachment to forks of lift truck } \\
\text { 7.2.1 Ability To safely use and } \\
\text { operate a forklift with an attachment } \\
\text { 7.2.2 Knowledge of how the specific } \\
\text { attachment now changes lifting } \\
\text { capacity and center of gravity } \\
\text { 7.3.1 Knowledge of warnings and } \\
\text { precautions of use from } \\
\text { manufacturer of forklift and }\end{array}$ \\
\hline
\end{tabular}




\section{Ergonomics International Journal}

\begin{tabular}{|c|c|c|c|}
\hline & & & Attachment \\
\hline 8. & Vehicle Capacity & $\begin{array}{l}\text { 8.1 Vehicles lifting capacity } \\
\text { 8.2 Capacity of vehicle itself }\end{array}$ & $\begin{array}{l}\text { 8.1.1 Knowledge of vehicles lifting } \\
\text { capacity and how to calculate } \\
\text { 8.2.1 Knowledge of the capacity of } \\
\text { vehicle itself }\end{array}$ \\
\hline 9. & Vehicle Stability & $\begin{array}{l}\text { 9.1 Center of gravity } \\
\text { 9.2 Traveling with a load } \\
\text { 9.3 Crossing railroad tracks }\end{array}$ & $\begin{array}{l}\text { 9.1.1 Knowledge of how the vehicles } \\
\text { center of gravity changes depending } \\
\text { on different situations } \\
\text { 9.1.2 Ability to stay aware of center } \\
\text { of gravity and when it changes } \\
\text { 9.2.1 Knowledge of how traveling } \\
\text { with a load effects the vehicles } \\
\text { stability } \\
\text { 9.2.2 Ability to maintain stability } \\
\text { while traveling with a load } \\
\text { 9.3.1 Knowledge of how to cross } \\
\text { railroad tracks while operating a } \\
\text { forklift }\end{array}$ \\
\hline 10. & $\begin{array}{l}\text { Pre-trip walkaround } \\
\text { inspection }\end{array}$ & $\begin{array}{l}\text { 10.1 Identify by looking for and } \\
\text { reacting when seeing leaks from a } \\
\text { forklift } \\
\text { 10.2 Recognize what to look for one } \\
\text { the wire and hydraulics by showing } \\
\text { which wires are in the best condition } \\
\mathbf{1 0 . 3} \text { Recall what a tire should look } \\
\text { like to preform work by selecting } \\
\text { any stresses on a tire }\end{array}$ & $\begin{array}{l}\text { 10.1.1 The user should be able to } \\
\text { understand the knowledge of where } \\
\text { leaks can happen } \\
\text { 10.2.1 The user should be able to } \\
\text { understand what to look for with } \\
\text { inspecting the wires and hydraulics } \\
\text { 10.3.1 The user should be able to } \\
\text { understand the stresses a tire can } \\
\text { show and report them }\end{array}$ \\
\hline 11. & $\begin{array}{l}\text { Refueling and/or charging and } \\
\text { recharging of batteries }\end{array}$ & 11.1 Safe refueling practices & 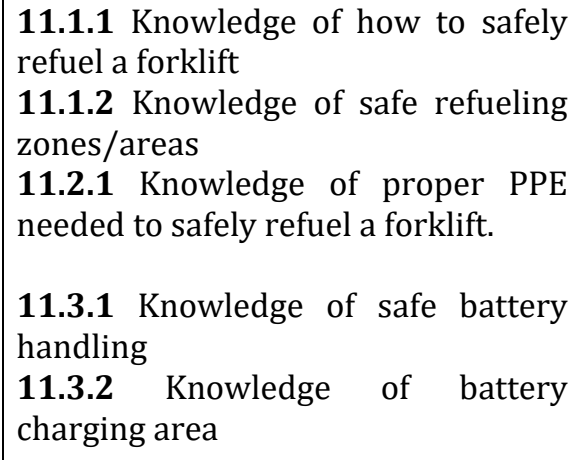 \\
\hline 12. & $\begin{array}{l}\text { Handle materials with the } \\
\text { forks }\end{array}$ & $\begin{array}{l}\text { 12.1 Operate the forklift slowly and } \\
\text { safely when approaching a load } \\
\text { 12.2 Demonstrate the ability to lift a } \\
\text { load with the forks } \\
\text { 12.3 Demonstrate the ability to drive } \\
\text { the forklift in reverse with a load } \\
\text { 12.4 Illustrate how to load a load } \\
\text { onto a higher shelf } \\
\text { 12.5 Demonstrate the ability to }\end{array}$ & $\begin{array}{l}\text { 12.1.1 The user should be able to } \\
\text { know to approach a load safely } \\
\text { 12.2.1 The user should be able to } \\
\text { show ability with the forks } \\
\text { 12.3.1 The user should be able to } \\
\text { move a load in reverse } \\
\text { 12.4.1 The user should be able to } \\
\text { move pallet to higher location } \\
\text { 12.5.1 The user should be able to }\end{array}$ \\
\hline
\end{tabular}




\section{Ergonomics International Journal}

\begin{tabular}{|c|c|c|c|}
\hline & & $\begin{array}{l}\text { unload a load with the forks } \\
\text { 12.6 Illustrate how to unload a load } \\
\text { from a higher shelf } \\
\text { 12.7 Demonstrate ability to exit } \\
\text { safety from a shipping container } \\
\text { 12.8 Demonstrate ability to exit } \\
\text { safely from a shipping container } \\
\text { 12.9 Illustrate how to unload a load } \\
\text { from a shipping container }\end{array}$ & $\begin{array}{l}\text { understand how to successfully } \\
\text { unload a pallet with the forks } \\
\mathbf{1 2 . 6 . 1} \text { The user should be able to } \\
\text { understand how to unload a pallet } \\
\text { on a high shelf } \\
\mathbf{1 2 . 7 . 1} \text { The user should be able to } \\
\text { maneuver in a shipping container } \\
\text { with a load } \\
\mathbf{1 2 . 8 . 1} \text { The user should be able to } \\
\text { load a pallet in a container and exit } \\
\text { safely } \\
\text { 12.9.1 The user should be able to } \\
\text { understand how to unload a } \\
\text { shipping container }\end{array}$ \\
\hline 13. & Determine the type of forklift & $\begin{array}{l}\text { 13.1 Recognize the importance of } \\
\text { knowing the different power source } \\
\text { for the forklift by selecting power } \\
\text { source such as the propane source. } \\
\text { 13.2 Classify the type of tire on the } \\
\text { forklift } \\
\text { 13.3 Calculate the center of gravity } \\
\text { triangle when carrying a load }\end{array}$ & $\begin{array}{l}\text { 13.1.1 The user should be able to } \\
\text { determine what the forklift is } \\
\text { powered by } \\
\text { 13.2.1 The user should be able to } \\
\text { identify the differences in tires of a } \\
\text { forklift } \\
\text { 13.3.1 The user should be able to } \\
\text { understand the center of gravity } \\
\text { triangle with carrying a load }\end{array}$ \\
\hline 14. & $\begin{array}{c}\text { Return the forklift to parking } \\
\text { spot or charging station }\end{array}$ & $\begin{array}{l}\text { 14.1 Demonstrate ability on how to } \\
\text { park properly } \\
\text { 14.2 Apply ability to turn off the } \\
\text { forklift } \\
\text { 14.3 Understand the importance of } \\
\text { putting the forklift on charge and } \\
\text { ability on how to do so }\end{array}$ & $\begin{array}{l}\text { 14.1.1 The user should be able to } \\
\text { understand how to properly park } \\
\text { 14.2.1 The user should be able to } \\
\text { operate how to turn off the forklift } \\
\text { 14.3.1 The user should be able to } \\
\text { know the importance of putting the } \\
\text { forklift on charge and how to do so }\end{array}$ \\
\hline
\end{tabular}

Table 2: The Forklift Maneuvering: task analysis, terminal objective and skill.

We wanted that the trainees learn about the value of regulatory compliance for the forklift operation. Hence, we have listed OSHA standards needed for each step in the following.

Step 1: 29 CFR 1910.178(I)(3)(i)[A]

Step 2: 29 CFR 1910.178(I)(3)(i)[B]

Step 3: 29 CFR 1910.178(I)(3)(i)[C]

Step 4: 29 CFR 1910.178(I)(3)(i)[D]

Step 5: 29 CFR 1910.178(I)(3)(i)[E]

Step 6: 29 CFR 1910.178(I)(3)(i)[F]

Step 7: 29 CFR 1910.178(I)(3)(i)[G]

Step 8: 29 CFR 1910.178(I)(3)(i)[H]

Step 9: 29 CFR 1910.178(I)(3)(i)[I]

Step 10: 29 CFR 1910.178(I)(3)(i)[J]

Step 11: 29 CFR 1910.178(I)(3)(i)[K]

Step 12: 29 CFR 1910.178(I)(3)(i)[M]

\section{Evaluation of the Training Program}

To find out if the instruction worked, it is very important to recognize test items that are appropriate for measuring accomplishment of an objective. Norm referenced tests are intended to find out how well one person's performance is compared to that of other people. It is similar to the traditional tests that are given in schools. The criterion referenced tests are called a criterion test or skill check and it evaluates whether the objectives of a task have been mastered. It asks the trainee to do exactly what the objectives call for.

To evaluate the trainee for forklift skills, we have attached some criterion items. These criterion items show the objectives satisfied for each step and ways to test those skills. The following sections show the objectives 


\section{Ergonomics International Journal}

needed to be satisfied by fulfilling each of these criterions. To draft the criterion items, we were able to recognize all the steps for forklift operation. We performed the following procedure for determining whether a criterion item is appropriate for testing accomplishment of an objective:

a. Step 1: Checked that the performance called for by the criterion item is the same as that called for by the objective.

b. Checked that the conditions under which the test item will be administered are as close as possible to those stated in the objective.

\section{Objectives and Criterions for Each Skill Mentioned under Table 2.}

- Objective for skills associated with task 1: Given the information provided in the training session, the trainees will be able to identify and differentiate OSHA regulations and warnings by demonstrating this in a hands-on evaluation.

- Objective for skills associated with task 2: Given a demonstration and training video, trainees will understand and effectively portray how a forklift steering is reversed compared to a car and able to explain the load position.

- Objective for skills associated with task 3: Given a training session detailed on forklift control functions, the trainees will have knowledge of the instrumentations and control functions of each while displaying their knowledge by passing a quiz at the end of the session.

- Objective for skills associated with task 4: Given a forklift, the trainee will demonstrate his/her ability of recognizing and knowing the basic engine/motor function by turning on and powering off their lift and performing a pre-task checklist.

- Objective for skills associated with task 5: Given an obstacle training course, the trainee will operate the course by not hitting even one cone (from a series of multiple cones laid in the trajectory) and be required to move pallets from several locations to demonstrate the ability to operate the lift truck in a safe manner.

- Objective for skills associated with task 6: The operator will be placed in a simulation course which will provide results of the operator's ability to maintain visibility, knowledge of when to use a spotter, pedestrian awareness and awareness of other forklifts.

- Objective for skills associated with task 7: Given a quiz at the end of the training course the trainee will demonstrate his/her knowledge gained of the

Priyadarshini DG, et al. An Ergonomic Forklift Training Program. Ergonomics Int J 2019, 3(4): 000212. components and fundamentals of forklift attachments by scoring $100 \%$ on quiz.

- Objective for skills associated with task 8: Given several scenarios and different load weights and lift truck lifting capabilities the trainee will calculate the forklift limitations for each individual scenario with 100\% accuracy.

- Objective for skills associated with task 9: The trainee will demonstrate his or her knowledge gained from this course of how the center of gravity changes, awareness of when center of gravity changes, how a load affects the stability, and how to cross a railroad track through a hands-on evaluation with the instructor.

- Objective for skills associated with task 10: Given a preoperation checklist the trainee will fill out the checklist and perform a visual inspection to display understanding of the inspection and identifying maintenance needed.

- Objective for skills associated with task 11: Given a forklift the trainee will perform the effective means for refueling the lift truck whether it is diesel, propane, or battery to demonstrate that they understand the proper procedures to safely refuel the forklift.

- Objective for skills associated with task 12: Given the operator manual the trainee will read through it and take a knowledge evaluation, and pass with $100 \%$ accuracy, to demonstrate their ability to take an operator's manual and effectively find the necessary information within the manual when needed.

\section{Comparison of the Ergonomic Training Program}

Once the forklift training program was finalized, it was decided that it should be shown to companies that use forklifts on a regular basis to collect their thoughts on it and to see if they would be willing to adopt it. A questionnaire was made in order to collect data in a uniform fashion. The questionnaire included the following questions: How do you rate the existing forklift program in your business? Can you find a difference between the forklift program that we developed and yours? If you are given this program, would you like to continue with it for forklift training? Why or why not? Do you find a methodical structure of our program? And Can you suggest any alterations to our program?

The first business that was visited was Target located in the Hammond Square Mall in Hammond, LA. The author was able to speak to the individual in charge of training the forklift operator. He said he would rate their 


\section{Ergonomics International Journal}

existing program as good. A major difference between their forklift program and ours is that it is mostly online and then has a hands-on portion at the end. He said that if he were given the program, he would try to incorporate it into their training procedures but, is unable to due to corporate policies stating that all targets must use the same training procedure that is sent out by corporate. He said that he agrees that there is a methodical structure to our program and the only alteration that he could think of was to expand on each individual skill [5-10].

The author was able to speak to one of the managers in Academy Outdoors manager who is responsible for training the forklift operators and we showed him what we had developed. He rated their existing training program as good. He stated that the biggest difference between their training program and ours is that they use a lot of online modules and then end with a hands-on test. He said that if it were up to him, he would use our training program to train his workers. However, corporate says that all Academy locations must use the forklift training program that they use. He said that he agrees that our program has a definite methodical approach. He suggested that we add a section about breaking because different forklifts have different breaking processes.

\section{Discussion}

The purpose of training program in any occupational setting is to bring about a desired change in the work process, such as to reduce workers' injury and/or illness risks. The need to carry out a training program is often related to a desired modification in the task process, introduction of new tools or technologies or noncompliance issues of workers over work policies. In our model training program, we used instructional objectives which were derived from described competent performance of forklift operation in the real world. The use of objectives and skill checks in our model training program introduced clarity of purpose, well-crafted criterion and evaluation in the training program. Therefore this can serve as a basic training program where the trainer will be able to communicate clear expectations and criterions for the trainees that they need to perform in order to get a certificate of the training. It is noteworthy that the other training programs we evaluated, did not have clear criterion items and without those trainees can be open to the charge that the trainer did a bad job of training.

The objective based learning is useful due to the usage of the following: (1) behavior, (2) condition and (3) degree. The behavior, as was referred similar to a "performance" will help achieving the goal of objective that was described as the "doing". We strongly emphasized that the trainers use a verb to describe a desirable behavior that was "observable" by the trainer. The strength of our training program specifically lies here because most of the other training programs did not set an "observable behavior" as a performance criterion in their training programs. Also, an objective always described the important condition under which the performance was to occur. It is noteworthy that, whenever possible, an objective described the criterion of acceptable performance in order to describe how well the learner must perform in order to be considered acceptable. The conditions specified the work condition under which the performance needs to take place. For example, if a trainee needs to show the loading and unloading of a forklift, she would rather choose an area with predetermined loads and places to keep those loads. We have also emphasized the degree to which the trainee needs to be accurate.

The main advantage of our training program is that it specified the exact skills which is supposed to be learned by the trainees. Hence it reduces the dilemma about instruction not only to the trainees but is helpful for the trainers throughout the learning process and in the evaluation process. Another advantage of the training program is that the objectives are basically statements that clearly describe an anticipated learning outcome. The objectives clearly imply what the trainees can do after the training program that they might not have been able to do before the program began.

Our training model is unique because we took care of both the overt (that can be observed directly whether visible and audible) and covert (the performances that can not be observed directly; mental, invisible, internal or cognitive) behavior. We have kept opportunities for the trainer to add indicator behaviors to the covert behaviors so that the trainees perform skills that can not be directly observed. For example, if the trainee needed to safely maneuver and back off the forklift, the trainer could not assume to put people or property behind the forklift to test whether the trainee can safely maneuver. Hence the trainer can place six safety cones behind the forklift and expect that the trainee would maneuver the forklift without turning down even one cone.

\section{References}

1. Craven Community College (2018) Forklift Training Program. 


\section{Ergonomics International Journal}

2. Dangelo J, Snyder M, Bleedorn J, Hardie R, Foley E, et al. (2019) An Interdisciplinary Approach to Surgical Skills Training Decreases Programmatic Costs. J Surg Res 235: 600-606.

3. De Bruecker $\mathrm{P}$, Beliën J, Van den Bergh J, Demeulemeester E (2018) A three-stage mixed integer programming approach for optimizing the skill mix and training schedules for aircraft maintenance. European J Operational Res 267(2): 439-452.

4. State of Washington (2007) Forklift Safety Guide State of Washington.

5. Sample Forklift Safety and Powered Industrial Trucks Written Program, PMA Companies.
6. San Jose State University (2005) Forklift Training Manual.

7. Schneider W (1985) Training High Performance Skills: Fallacies and Guidelines. Human Attention Res Lab 27(3): 285-300.

8. Smith TD, Herron R, Le A, Wilson JK, Marion J, Vicenzi DA (2018) Assessment of confined space entry and rescue training for aircraft rescue and firefighting (ARFF) members in the United States. J Safety Res 67: 77-82.

9. University of Pittsburgh (2002) Safety Requirements Powered Industrial Truck Program.

10. Vigilant Council for Employers. Forklift Training for Trainers. 